\title{
Assessing Common Errors in Students' Guided Writing in Case of First Year Social Science and Humanities Studensts at Kabridahar University
}

\author{
Mulugeta Asnakew Tadesse \\ Assistance Lecturer at Kabridahar University, College of Social Science and Humanities, Department of English \\ Language and Literature
}

\begin{abstract}
This study was conducted on Assessing common errors in students guided writing: The case of first year social science and humanities students at Kabridahr University. It is aimed to identify the frequent errors that students make during guided writing and the challenges that affect the students' guided writing. The objective of the study was to find out the students' errors in guided writing. Descriptive type research design was employed to achieve the objectives and address to research the problems by qualitative and quantities used descriptive methods to express the problem affect students in guided writing. The data were collected by questionnaire, interview and documentary analysis. The study identified that the most frequent errors made by students are grammatical and syntactic errors. Especially the assignment and interview show that students make error in tense and grammar rules. In general, almost all the students make an error in putting their ideas in writing only. The study recommends, that to improve the student's paragraph writing, it must be needed time and practice many times with in the class
\end{abstract}

DOI: $10.7176 /$ JLLL/79-03

Publication date:May $31^{\text {st }} 2021$

\section{Background of the study}

Writing is one of the major language skills through which one expresses his/her ideas. Writing, like speaking, is one way of communication. This means writing is another medium through which people communicate. In order to develop effective writing, teachers are responsible people to give students to practice in organizing their writing students' role is also maximum.

Writing is a method of expressing language in visual or tactile form. Writing system use sets symbols to represent the sound of space and may also have symbols for sound things as punctuation and numeral. Tyner (1987:4).

Writing is a powerful instrument for students to use to express their thoughts, feeling, and judgments about what they have read, seen, or experience. As students continue to develop an understanding of the writing process, the element of writing, text forms, genres, and formats, and technology, they are as to express themselves, more confidently and effectively. ( Hughes 1986) .

Teacher use their professional judgment and careful observation in order to provide explicit instruction that will support students as they became effective writers.

Because of the inter connectedness of reading and writing guide builds a material already presented in A Guide to effective instruction in reading. Young writes need to experience sustained and successful Guided writing lessons are temporary, small group lessons teaching those strategies that a group of students most need to practice with immediate guidance. Guided writing lessons can be taught after hole-class lesson once other students are actively engaged in dependent writing (Needleman 1968) Writing is learned through apprenticeships, as teachers assist students during writing using guided practice.

Many students need this expert guidance in a small-group context, particularly as they attempt to bridge the got between the teacher's demonstration and modeling and their own independent writing.

Young and poor writers have limited control over strategies for writing. Those writers do, however learn strategic behavior for writing when these strategies are taught to them in clear and supportive ways. When authentic and targeted modeling of the ways in which writers work is presented by teachers and co-constructed with students during collaborative, rich discussion, learners develop understanding of the purposes, intrinsic motivation, and technique of writing. Several excellent frameworks for writing instruction accomplish these goals, including modeled, shared, interactive, guided or independent writing.

During guided writing instruction, in particular, students are providing with opportunities to experience successful and independent writing within the context of strong teacher support.

Guided writing is an essential component of a balanced writing curriculum, providing an additional supported step towards independent writing. It contributed to the teaching sequence as exemplified in the primary Framework. Through guided writing, student is supported during the different stages of the writing process. 


\section{Statement of the problem}

Students can get the ability of writing through writing; however, they might make an error. This research was intended to identify the common errors that students committed when they write. From the previous personal experiences their writing fails to be the sentence, lack conjunction, punctuation etc. and also lack topic sentence and supporting details may not adequately describe the topic sentence and these not relationship between ideals.

According to Mohammed Hessen research that done in Addis Ababa University on assessing common errors in paragraph writing it depends on some errors on paragraph such as run -on, misplaced modifier, and sentence fragment. Those errors are not enough to develop effective writing skills. This is why the researcher initiated to study this issue. The researcher decided to assess common errors in students guided writing.

\section{Research Questions}

1. What are common error types which students make when they write?

2. What measures should be taken to minimize errors in students guided writing?

3. What are the factors that affect student's guided writing?

\section{General objective of the study}

The main objective of the study is to identify students 'common errors in guided writing.

\section{Specific Objective}

The specific objective of the study

To identify the most frequent error types students, make in guided writing.

To distinguish possible measures to minimize students' errors in guided writing.

To assess the factors that affects the students guided writing.

\section{Significance of the study}

The result of the study is expected to benefit both students and teachers. It can help teachers to identify the errors of the students in guided writing and to motivate their students to write effectively. It would help students to understand and improve their problems. Lastly, it can serve as a source for other researchers who plan to do further research on the area.

\section{Delimitation of the study}

They study focus on common errors in students guided writing, in the cause of first year college of social science and humanities at Kabridahr University.

\section{Limitation of the study}

The researcher faced several challenges such as the students were unwilling to offer accurate information, the researcher faced lack of sufficient time, money, necessary materials, internet access and experience to conduct the research effectively. Furthermore, the respondents were late to give the questionnaire to the researcher. Despite of these problems the researcher conducted the study fruitfully.

\section{METHODOLOGY}

\section{DESIGN OF THE STUDY}

Descriptive type of research design was employed to achieve the objective and address problem by qualitative and quantitative approach. The researcher chooses the interpretation of qualitative and quantitative and used descriptive methods to express the problem that affect the students guided writing. So, in the range of the study the researcher was conducted descriptive research.

\section{SUBJECT OF THE STUDY}

This research was conducted on first year social science and humanity students of Kabridahar University.

\section{SAMPLING TECHNIQUES}

The researcher was used random sampling technique to select sample representatives. Because gathering information from each student was difficult and consuming. According random sampling technique was employed to select a representative sample of 45 students.

Available sampling was used to choose 5 of English Language teachers who participate for questionnaire.

\section{DATA GATHERING TOOLS QUESTIONNAIRES}

The researcher was preparing questionnaires for the selected students and instructors. The questionnaires 
included both close-ended and open- ended questions. The researcher distributed questionnaire to 45 students of first year social science and humanities and five (5) to teachers to collect information. The researcher used questionnaire because questionnaire is better to gather information from huge number of students.

\section{INTERVIEW}

The interview will give for both instructor and students of first year social science and humanities in semi structured manner. Because this is possible to get more detail for the study.

The researchers select 8 students and 3 instructors for interview from the college, in order to save time and budget. The researchers also prepare 5 and 3 for instructor.

\section{DOCMNT ANALYSIS}

The students' document was the other tool that the researcher was used data from students' paper. In this the researcher had collected any written paper from the respondents. Because, this method assisted common errors on students in their writing.

\section{METHOD OF DATA ANALYSIS}

The data gathered through questionnaire, interview and document analysis is analyzed qualitatively and quantitatively. In other word, the researcher used percentage to record the data found from students' and teachers' questionnaire. The open-ended questions of questionnaire and data gathered through interview and document analysis are analyzed in words thoroughly.

\section{DATA ANALYSIS AND INTERPRETATION}

In this chapter data that was obtained from questionnaire, interview and test is going to be analyzed.

Table 4.1 the respondent background information about their sex.

\begin{tabular}{|l|l|l|}
\hline Sex & No, respondent & Percentage \\
\hline Male & 33 & $66 \%$ \\
\hline Female & 17 & $34 \%$ \\
\hline Total & 50 & $100 \%$ \\
\hline
\end{tabular}

The table shows that the manner of participants and their relative sex distribution information when the researcher use to analyze and interpret the study based on the respondent's information both sexes have different chance on the study.

\section{Analysis and interpretation of students' questionnaire}

Analysis of students close ended questions

Table 4.2. 1.1The student's response on what the common errors they mostly commit when they write.

\begin{tabular}{|l|l|l|l|}
\hline Item & Variable & No of respondent & Percentage \\
\hline $\begin{array}{l}\text { What common errors do you most commit } \\
\text { when you write? }\end{array}$ & A, spelling errors & 16 & $36 \%$ \\
\hline & B, punctuation errors & 7 & $15 \%$ \\
\hline & C. tense mistakes & 8 & $18 \%$ \\
\hline & D, all type & 14 & $31 \%$ \\
\hline Total & & 45 & $100 \%$ \\
\hline
\end{tabular}

As it indicated in the above table, most of the students' errors are common in their writing.

The table show that $36 \%$ of respondent said that they make all errors from the choice. These are: spelling errors, tense mistake, and punctuation errors. Most of students agreed up on their writing have occurred on errors, with spelling errors $31 \%$, tense mistake $18 \%$, punctuation errors $15 \%$, and all type of errors $31 \%$. Therefore, from the above responses it can be conclude that most of the students make errors when they write. Because all most all respondents answered they make an errors in spelling errors punctuation errors, and tense mistake are the most common errors in their writing.

Table 4.2.1.2 Students responses on what helps them more to develop their writing skill

\begin{tabular}{|l|l|l|l|}
\hline Item & Variable & No of respondent & Percentage \\
\hline $\begin{array}{l}\text { Which of the following helps you } \\
\text { to develop your writing skills? }\end{array}$ & $\begin{array}{l}\text { A, practicing in class continuously with } \\
\text { a teacher }\end{array}$ & 9 & $20 \%$ \\
\hline & B, practicing writing outside the class & 8 & $17 \%$ \\
\hline & $\begin{array}{l}\text { C, practicing writing in class room with } \\
\text { in groups }\end{array}$ & 12 & $27 \%$ \\
\hline Total & D, all & 16 & $36 \%$ \\
\hline
\end{tabular}


The above table indicates $36 \%$ of responds agreed on practicing writing in their class continuously with teachers, outside the class and in the class room with groups and also $27 \%$ of respondent agreed that practicing writing in the class room with in groups, $20 \%$ of respondents agreed that practicing in the class continuously with a teacher and practicing writing outside the class $17 \%$.

Table4.2.1.3 Student's response on how often their teachers motivate them in writing class.

\begin{tabular}{|l|l|l|l|}
\hline Item & Variable & $\begin{array}{l}\text { No } \\
\text { respondent }\end{array}$ & Percentage \\
\hline $\begin{array}{l}\text { How often does your teacher motivate you to write in } \\
\text { class? }\end{array}$ & $\begin{array}{l}\text { A, most of the } \\
\text { time }\end{array}$ & 23 & 51 \\
\hline & B, sometimes & 15 & $33 \%$ \\
\hline & C, Rarely & 7 & $16 \%$ \\
\hline D, never & & 45 & $100 \%$ \\
\hline
\end{tabular}

The above table shows the most respondents (51\%) of them answered that their teachers give writing task most of the time; $33 \%$ of the respondents replied that their teachers sometimes motivate them to write in the class and 16\%oof the respondent answered that their teachers rarely motivate them to write in the class. But a few respondent responses shows that the problem is concerned student's carelessness and incomplete application of the rules, but their teachers give writing.

Table 4.2.4 students 'response on does their teacher give immediate feedback on their writing.

\begin{tabular}{|l|l|l|l|}
\hline Item & Variable & $\begin{array}{l}\text { No } \\
\text { respondents }\end{array}$ & Percentage \\
\hline $\begin{array}{l}\text { Does your teacher give you an immediate feedback on your } \\
\text { writing }\end{array}$ & A, yes & 34 & $76 \%$ \\
\hline & B, no & 11 & $24 \%$ \\
\hline Total & & 45 & $100 \%$ \\
\hline
\end{tabular}

From the above table most of the respondents (76\%) said that their teacher gives immediate feedback for their writing. On the other hand $(24 \%)$ of the respondent replied that their t teachers did not give immediate feedback. Based on the majority respondents the teacher gives immediate feedback for the student $s$ writing. Their fore the teachers are more responsible to develop students writing by giving feedback.

Table 4.2.5. Student's response on how group assignment helps to improve their writing skills.

\begin{tabular}{|l|l|l|l|}
\hline Item & Variable & $\begin{array}{l}\text { No } \\
\text { respondents }\end{array}$ & Percentage \\
\hline $\begin{array}{l}\text { Do you believe that group assignment can help you to improve your } \\
\text { writing skills? }\end{array}$ & A, yes & 32 & $71 \%$ \\
\hline & B, no & 13 & $29 \%$ \\
\hline Total & & & $100 \%$ \\
\hline
\end{tabular}

As it indicates the above table, there are different believes about group writing. The majorities about (71\%) of the respondent believed that group writing is the most important for them. Other (29\%) of the respondents' believed that group writing necessary for them. Students said that when they write group assignment, they improve their writing. The problems are different when someone make errors other might improve his or her problems.so, to conclude that group writing proved them to help each other.

Table 4.2.6. Students' response on do they evaluate their writing.

\begin{tabular}{|l|l|l|l|}
\hline Item & Variable & No of respondents & Percentage \\
\hline Do you evaluate your writing? & A, yes & 32 & $71 \%$ \\
\hline & B, no & 13 & $29 \%$ \\
\hline Total & & & $100 \%$ \\
\hline
\end{tabular}

From the above table most of respondents (71\%) said that they evaluate their writing. $28 \%$ of them replied they do not evaluate their writing by themselves. Therefore, these information indicate that most of the students evaluate their writing by themselves.

Table 4.2.7 Students' response on how they evaluate their writing skills well.

\begin{tabular}{|l|l|l|l|}
\hline Item & variable & $\begin{array}{l}\text { No } \\
\text { respondents }\end{array}$ & Percentage \\
\hline $\begin{array}{l}\text { If your answer for question number 6 is true, how you evaluate } \\
\text { your writing skills? }\end{array}$ & $\begin{array}{l}\mathrm{A}, \text { very } \\
\text { good }\end{array}$ & 11 & $24 \%$ \\
\hline & $\mathrm{B}$, good & 26 & $58 \%$ \\
\hline & $\mathrm{C}$, not bad & 4 & $9 \%$ \\
\hline Total & $\mathrm{D}$, not good & 4 & $9 \%$ \\
\hline
\end{tabular}


The above table indicate that most (58\%) of the respondents believed that their writing skills good and also $(24 \%)$ of the respondents said their writing is very good and a few $(9 \%)$ of the respondent said their writing is not bad and at the same numbers of the respondents $(9 \%)$ said their writing is not good. Therefore, most of the respondent's answer organized their writing is well organized and to give complete meanings. Ideas in addition indicated they have good writing skill.

Table 4.2.8 students' responses on do they get enough time to practice writing skills.

\begin{tabular}{|l|l|l|l|}
\hline Item & variable & No of respondents & Percentage \\
\hline do you think that you have enogh time to practice writing skills ? & A, yes & 4 & $9 \%$ \\
\hline Total & B, no & 41 & $91 \%$ \\
\hline
\end{tabular}

As indicated above, (91\%) believed that they haven't get enough time to practicing writing skills .9\% of the respondents said that the have enough time to practice their writing skills. Therefore, producing organized writing needs enough time. There are many processes in writing so they need many times. From these information students have not enough time to practicing writing skills.

Table 4.2.9 students' responses what problems mostly occurs when they write.

\begin{tabular}{|l|l|l|l|}
\hline Item & Variable & $\begin{array}{l}\text { No } \\
\text { respondents }\end{array}$ & Percentages \\
\hline $\begin{array}{l}\text { Which type of problem mostly occurs when you } \\
\text { write? }\end{array}$ & A, sentence fragments & 11 & \\
\hline & B, dangling modifier & 11 & \\
\hline & C, misplaced modifier & 4 & \\
\hline & D, all of the above & 19 & \\
\hline Total & & 45 & \\
\hline
\end{tabular}

The above table show greatest number of respondents (19\%) expected that they faced all problems with in their writing and $11 \%$ as a respondent said faced sentence fragment at the same percentage also, they faced dangling modifier. And also 4\% expressed they faced misplaced modifier. Therefore, most of the respondents identified that incomplete ideas, ungrammatical and utterance and unnecessary repletion of sentence are the most common in students writing.

Table 4.2.10 student's response on con they correct their errors in writing by themselves.

\begin{tabular}{|l|l|l|l|}
\hline Item & Variable & No of respondents & Percentage \\
\hline Can you correct your errors in writing by yourselves? & A, yes & 41 & $91 \%$ \\
\hline & B, no & 4 & $9 \%$ \\
\hline Total & & 45 & $100 \%$ \\
\hline
\end{tabular}

From the above table most of the respondents (91\%) said that they correct errors in writing by themselves.

However, a few numbers of respondents (9\%) said that they do not correct their writing by themselves.

Therefore, the students they can correct their writing by themselves.

Table 4.2.1.11 students' response what methods their teachers use in teaching writing class.

\begin{tabular}{|l|l|l|l|}
\hline Item & Variable & No of respondents & Percentage \\
\hline $\begin{array}{l}\text { Which methods do your teacher uses in } \\
\text { teaching writing class? }\end{array}$ & A, student-centered method & 2 & $5 \%$ \\
\hline & B, teacher- centered method & 10 & $22 \%$ \\
\hline Total & C, both & 33 & $73 \%$ \\
\hline
\end{tabular}

From the above table (73\%) of the respondents said that their teachers mostly use both student and teacher center in teaching writing class. The others $5 \%$ of the said that their teachers use student centered and $22 \%$ of the respondents said that their teachers use teacher centered. Therefore, from this information we see teachers use both students centered and teacher centered in teaching writing class.

Table 4.2.1.12 Students responses on what level of writing is difficult for them.

\begin{tabular}{|l|l|l|l|}
\hline Item & Variable & No of respondents & Percentage \\
\hline What do you think are the most difficult level writing? & A, sentence level & 30 & $67 \%$ \\
\hline & B, paragraph level & 10 & $22 \%$ \\
\hline & C, essay level & 5 & 11 \\
\hline Total & & 45 & $100 \%$ \\
\hline
\end{tabular}

The above table indicate that $67 \%$ of the respondents said that sentence level writing is difficult $.22 \%$ of the respondents said that paragraph level writing is difficult and $5 \%$ of said that essay level is difficult. Therefore, as we see from the information from student's response sentence level writing is difficult level of writing. 
Table 4.2.1.13 Students responses on what do they think are most important in overcoming with errors in writing skill.

\begin{tabular}{|c|c|c|c|}
\hline Item & Variable & $\begin{array}{l}\text { No of } \\
\text { respondents }\end{array}$ & Percentage \\
\hline $\begin{array}{l}\text { what strategies do you think are most important in } \\
\text { overcoming with errors in writing skill? }\end{array}$ & $\begin{array}{l}\text { A, understanding the steps } \\
\text { of writing }\end{array}$ & 38 & $84 \%$ \\
\hline & $\begin{array}{l}\text { B, understanding } \\
\text { components of writing }\end{array}$ & 7 & $16 \%$ \\
\hline Total & & 45 & $100 \%$ \\
\hline
\end{tabular}

As we can see from the table 4.2.1.13, $84 \%$ of the students said that understanding the steps of writing is most important in overcoming with errors in writing and $16 \%$ of the respondents said that understanding components of writing. Therefore, majority of the students overcoming with errors by understanding the steps of writing.

\section{Analysis of students open ended questions}

1. If your teacher gives you immediate feedback, how often your teacher gives you feedback; if not, what do you think is/are the reason?

The majority of the students said that their teachers give immediate feedback on their writing. They also give a response how often their teacher gives immediate feedback. Most of the students said that their teacher most of the time give immediate feedback. A few students said that their teacher give immediate feedback sometimes. Therefore, as the majority of the student's response the teacher most of the time give immediate feedback.

2. If you can correct your errors in writing by yourself, how you correct your errors by yourself; if not, why you don't correct your errors by yourself?

Most of respondents said that they correct their errors in writing by themselves. They also stated how they correct errors in their writing by themselves. They correct by readings repeatedly and checking the theory that is from lecture notes or from references. Then after they check their writing they write again and correct their mistakes.

3. what do you think are the most difficult level writing? Put your explanation.

Majority of the students said that the most difficult level writing is sentence level. Because sentence is the base for others level. So, if the sentence failed their structure the other things already failed. That means writing sentence is very necessary for others level.

\section{Analysis of students' response through interview}

1. What type of errors do you mostly commit when you write?

According to the response of the students they make errors mostly like punctuation, spelling errors, misplaced modifier and subject verb dis agreement. In addition to this they said that they make mistakes such as missing the topic sentences, supporting ideas and conclusions and also lack coherence of their writing.

\section{What do you think the sources of your problems in your writing?}

As the most respondents said that the sources of their problems are as the first-year students, lack of vocabulary, grammar knowledge, and background competence. And other source of their writing problems is their week motivation towards the subject matter, and the teacher's weak practice to encourage their students to write.

\section{What do you think to improve your writing skill?}

As the students suggested that if they make practice continuously for any writing in English and if they read strategies of writing, they can improve their writing skill. And also, they said that if the s hare ideas with their friends.

\section{Analysis of the test}

There was simple paragraph written by students. The researcher tried to analysis and interpret the students "test "in writing they had different errors such as lack of subject verb agreement which is pillar of coherence and one key of writing meaning. Here is also spelling errors in the writing. A miss spelt word changed the meaning of whole written material. Because, it is difficult to know what the students to say whenever he gives some miss spelt word. Furthermore, there is a failure of using punctuation correctly. Sometime the students used commas instead of period, semicolon instead of colon which is not common in writing skill learner. In the someway, there was mistake in the use of right tense at the right time and place. Frankly speaking this is the headache and bottleneck of the students' writing. Moreover, the common errors in the students writing include syntactic lexical errors, and most of student's lack of topic sentence, lack of unity and coherence writing. 
Table 4.4.1 selected sentences from the sentences from their writing.

\begin{tabular}{|l|l|}
\hline No & Sample sentences in students writing \\
\hline 1 & $\begin{array}{l}\text { Early marriage should not be allowed in our culture because of It leads to d/t problems, such as } \\
\text { unnecessary pregnancy, unhealthy child is born, high blood lose, decreasing life on expectancy, } \\
\text { abnormal mind in the new born child and the mother can damage psychologically and blooded out of } \\
\text { normal period. }\end{array}$ \\
\hline 2 & \begin{tabular}{l} 
It declines the country economy. \\
\hline 3 \\
therefore, early marriage is less Favorable to live, to educate and to self - manage as compare to normal \\
marriage.
\end{tabular} \\
\hline 4 & $\begin{array}{l}\text { Generally, early marriage has negative Effects on the peoples in social, political, Economical and cultural } \\
\text { aspect of the nation. }\end{array}$ \\
\hline
\end{tabular}

The researcher analyzed the above sample sentences taken from the paragraph of the students in the following ways as a researcher sees each sentence, in the paragraph there are many errors in the paragraph such as a lack of topics sentences lack of subject verb agreement, puncture on spelling capitalization and others like diction and dangling.

Sentence 1. In this sentence there are some errors these are: spelling errors, comma splice, grammar error and capitalization errors. Spelling error is seen in the word "pregnancy" should be "pregnancy" and the word " normal" should be "normal". Capitalization error is that of the word "It" the letter" I" is not appropriate. For this sentence the appropriate letter is not capital. I revised this "it". There is also grammar error in this sentence that is the word "can" should be "can be". This is correct form.

Sentence 2. The mistake in this sentence is subject verb dis agreement. That is the word "country" should be "country's". Unless it is meaningless. The correct form is "It declines the country's economy. Therefore, students make errors in this sentence is subject verb dis agreement.

Sentence 3. In this sentence the letter" $t$ " is small but it should be capital. Therefore, there is capitalization error. The other error is punctuation error. That is after the word "Therefore" "comma (,)" should be live. But they do not use. Therefore, they make punctuation error. The correct form is "Therefore ..." The word "Favorable" also not written correct form. That means the letter " $\mathrm{F}$ " is capital but in this sentence it should be small. The correct form is "favorable". As we observe the sample sentence the students make errors mostly, they make capitalization error and comma splice.

Sentence 4. In this sentence there are two errors students make when they write. These are tense problem, spelling and capitalization. The spelling error is in the word "marriage" they write "marriage" this is a spelling error. The correct word is "marriage". This is tense problem. That is the phrase ".... early marriage has negative..." in this tense is unappropriated. The correct form is ".... early marriage has negative...." Therefore, the students' common errors are capitalization error and tense problem.

The general opinion of teachers towards the common errors in the students guided writings.

Table 4.5.1 Teachers they motivate their students on their writing skill.

\begin{tabular}{|l|l|l|l|}
\hline Item & Variable & No of respondents & Percentage \\
\hline Do you motivate your students on writing skill? & A, yes & 5 & $100 \%$ \\
\hline & B, no & & \\
\hline Total & & 5 & $100 \%$ \\
\hline
\end{tabular}

The teachers were asked to give their response about their teaching writing skill with giving motivation or not. According to their response $100 \%$ of subjects responded that they give a motivation for their students on writing skill.

Table 4.5.2 teacher's response do they organize their students to help each other.

\begin{tabular}{|l|l|l|l|}
\hline Item & Variable & No of respondents & Percentage \\
\hline Do you organize your students to help each other? & A, yes & 5 & $100 \%$ \\
\hline & B, no & & \\
\hline Total & & 5 & $100 \%$ \\
\hline
\end{tabular}

As it can observed from the above table all of the respondents (100\%) of the subjects replied that they organize their students to help each other. Therefore, we can suggest that organizing students important for writing skills.

Table 4.5.3 teachers' response on their thinking about the advantage of organizing students in writing class.

\begin{tabular}{|l|l|l|l|}
\hline Item & Variable & No of respondents & Percentage \\
\hline $\begin{array}{l}\text { If your response for question number 2 is yes, do you thin k } \\
\text { that organizing students has advantage in writing skill? }\end{array}$ & A, yes & 4 & $80 \%$ \\
\hline & B, no & 1 & $20 \%$ \\
\hline Total & & 5 & $100 \%$ \\
\hline
\end{tabular}

The above table indicated that $80 \%$ of the respondents believed that organizing students in writing class is 
important for the students writing skills and $20 \%$ of the respondents believed organizing is not important.

Therefore, from this information organizing students in writing class is advantage.

Table 4.5.4 teachers' response about the methods they mostly use in their teaching writing course.

\begin{tabular}{|l|l|l|l|}
\hline Item & Variable & $\begin{array}{l}\text { No } \\
\text { respondents }\end{array}$ & Percentage \\
\hline $\begin{array}{l}\text { Which methods do you mostly use in writing } \\
\text { class? }\end{array}$ & $\begin{array}{l}\text { A, students - centered- } \\
\text { method }\end{array}$ & 1 & $20 \%$ \\
\hline & B, teacher- centered-method & & \\
\hline & C, both & 4 & $80 \%$ \\
\hline Total & & 5 & $100 \%$ \\
\hline
\end{tabular}

As we can see from above table $80 \%$ of the teachers mostly use both teacher-centered and student-centered and $20 \%$ of the respondents use student centered.

Table 4.5.5 teachers' response about what level do they observed more errors in their students writing.

\begin{tabular}{|l|l|l|l|}
\hline Item & Variable & $\begin{array}{l}\text { No } \\
\text { respondents }\end{array}$ & Percentage \\
\hline $\begin{array}{l}\text { In what level do you observe more errors in your students } \\
\text { writing? }\end{array}$ & A, sentence level & 3 & $60 \%$ \\
\hline & $\begin{array}{l}\text { B, paragraph } \\
\text { level }\end{array}$ & 1 & $20 \%$ \\
\hline C, essay level & 1 & $20 \%$ \\
\hline Total & & 5 & $100 \%$ \\
\hline
\end{tabular}

The above table indicated that $40 \%$ of the respondents said that more of their students make errors on sentence level and $20 \%$ of them said that they observed common errors on their students in paragraph level; at the $20 \%$ of respondents said that the students make mistake on essay level.

\section{Analysis of teachers open ended questions}

4.6.1. If you motivate students on writing skills, how you motivate them; if you don't motivate them, why you don't motivate students on writing skill?

According to the response of teachers, they motivate students in writing skill. They also give a response how they motivate students in writing skill. They motivate students by approaching them out listening to what their problems are, designing tasks as per their interest and skill, by showing them that it's easy to develop a piece of writing if they stick to the steps they tell / show them.

4.6.2. If you organize students to help each other and you believe organizing students in writing class has advantage for writing, what are the advantage of organizing students inwriting class?

The majority of the teacher's response as they organize students in writing class. As a teacher they talk about its advantage. From their response the advantage of organizing students the in-writing class the following advantages. These are the students to share their knowledge and skills of writing, to develop the habits of cooperative learning and practice per evaluation are the most important advantage of organizing students to help each other.

\section{Analysis of the teachers' response through interview}

What do you think are the most common errors you observe in your students writing?

According to the response of the teachers they observed their students mostly make errors like grammatical errors and sentence fragments. In grammatical such as subject verb dis agreement and tense.

What do you think are the source to the students' errors in writing skill?

As most of the teacher's response that the source of the students' errors in their writing are lack of motivation to learn, lack of confidence, lack of practice and poor language back ground.

What are the ways you employ to help your students reduce these errors?

The most teachers suggested that to reduce the student's error in guided writing the teachers should always teach tense. Because if the students know tense, they can avoid errors in their writing and they also suggest that the teachers must motivate their students to write and give immediate feedback. Therefore, to reduce students writing errors teachers are a responsible person.

\section{Conclusions}

After detailed in the section of the result found with the instrument used it as arrived at its conclusion as observed from the students' paragraph. They have many errors of grammar syntax and lexical. Grammatically they do not know the rules of the language. Hence, the student used the part of speech and the arrangement of sentence structure was well organized. Based on the evidence within the students, writing of paragraph by giving 
a test and by analyzing document their paragraph is not good and not bad based on the rules that help to develop paragraph but their paragraph mostly lacks unity and coherence. In general, when the researcher comes to conclude many of their writing were full of fragmented and unorganized ideas some students began to write unrelated ideas and passed from one sentence to the next without linking them on the other hand mother tongue and second language interferences are found as one challenge of students that make them not to write errors free paragraph. This because most of the students try to translate words and sentences in mother tongue language to English directly.

\section{Recommendation}

This study aimed at not only identifying the errors in writing but also suggesting some solutions that help to solve the students' errors. The researcher commends the following based on the finding.

1. First the students writing to be well organized the teachers should guide and motivate the students how to write. I.e., guided approach is used to the students giving assistance such as a plan and method to flow ideas to give a complete meaning.

2. To improve the students guided writing, it must be needed time and practice many times with in the class and the teacher should give a feedback with in the class also take times, so it needs time to make students to write an organized writing.

3. Sufficient reference materials in grammar and writing course should be provided to the library. It makes the students to read more and to guide to preparation which leads students for better writing.

4. In the observation, the teachers give continuous assessment and necessary feedback to their students on their writing. Therefore, for future giving continues assessment and a necessary feedback can make the students improve their writing skill.

\section{REFERENCE}

Alamirew,G.(2008). College of writing skills. Addis Ababa. Addis Ababa University. Hughes, D. (1986). Glencoe English: composition, speech and grammar 12. California: Encino Company. Idbi,E.(1884). Writing with purpose. England. Loughton. Mifflin Company. John,k.(1995). Skill development methodology part: Addis Ababa University.

Kelly, M.(1988). Important element of good writing: Addis Ababa. Addis Ababa University Lorena,T.(1999) .the adequate of writing talk: Addis Ababa university. Addis Ababa University. Needleman,M.(1968).writing for academic purpose: Addis Ababa .Addis Ababa University press. Tyner (1987:4). Teaching writing skills. London and New York. 